\title{
COASTAL FORMS AND DEPOSITS IN BULGARIAN ANTARCTIC BASE AREA, LIVINGSTON ISLAND
}

\author{
Rossitza Kenderova $^{1}$, Christo Pimpirev ${ }^{1}$, Ahinora Baltakova ${ }^{1}$, Stefka Pristavova ${ }^{2}$ \\ ${ }^{1}$ University of Sofia St. Kliment Ohridski, 15 Tzar Osvoboditel, 1504, Sofia, Bulgaria \\ ${ }^{2}$ University of mining and geology St. Ivan Rilski, Studentski grad, 1700, Sofia, Bulgaria \\ rosica@gea.uni-sofia.bg; cpimpirev@yahoo.com; a.g.baltakova@gmai.com; spristavova@abv.bg
}

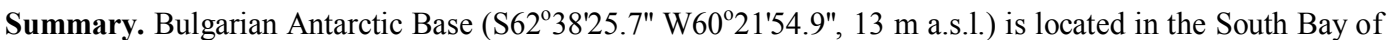
Livingston Island, South Shetland archipelago. The coast line has length of $1.8 \mathrm{~km}$ and it contains alternate sections with predominate abrasion or accumulation processes. This study comments the results of geomorphological and sedimentological investigations of deposits, which build the accumulative form complex: high and low marine terrace, pebble beach and at some places moraines. In abrasion areas are developed bench and cliff with niches, which are described only.

Key words: coastal forms and deposits, marine accumulative terrace, abrasion, granulometric and macroscopic analyses
\end{abstract}

Береговые формы отложений в районе Болгарской антарктической базы на о. Ливингстон.

Кендерова Росица, Пимпирев Христо, Балтакова Ахинора (Софийский университет им. Климента Охридского, София, Болгария, 1504, бул. Царя Освободителя, 15), Приставова Стефка (Университет горного дела и геологии им. Ивана Рильского, София, Болгария, Студенческий город, 1700)

Резюме. Болгарская база расположена на берегу Южного залива на острове Ливингстон, архипелаг Южные Шетландские острова. Длина береговой полосы составляет 1,8 км, на всем её протяжении наблюдается чередование абразивных и акумулятивных участков. Настоящая работа представляет результаты геоморфологических и седиментологических исследований отложений, которые составляют комплекс акумулятивных форм: высокую и низкую морские террасы, галечный пляж и местами морены. В абразивных участках развиваются бенч и клиф с нишами, описание которых представлено. Ключевые слова: береговые формы и депозиты, морская акумулятивная терраса, абразия, гранулометрический и макроскопический анализ

Берегові форми відкладень у районі Болгарської антарктичної бази на о-ві Лівінгстон. Кендерова Росіца, Пимпирєв Христо, Балтакова Ахінора (Софійський університет ім. Климента Охридського, Софія, Болгарія, 1504, бульв. Царя Визволителя, 15), Приставова Стефка (Університет гірничої справи і геології ім. Івана Рильського, Софія, Болгарія, Студентське місто, 1700)

Резюме. Болгарська база розташована на березі Південної затоки на острові Лівінгстон, архіпелаг Південні Шетландські острови. Довжина берегової смуги складає 1,8 км, на всьому іiі протязі спостерігається чергування абразивних та акумулятивних ділянок. Дана робота представляє результати геоморфологічних і седіментологічних досліджень відкладень, які складають комплекс акумулятивних форм: високу й низьку морські тераси, гальковий пляж та місцями морени. В абразивних ділянках розвиваються бренч і кліф з нішами, опис яких представлено.

Ключові слова. Берегові форми і депозити, морська акумулятивна тераса, абразія, гранулометричний і макроскопічний аналіз

The geomorphological studies on Livingston Island are part of the scientific project under the name "Geological, geochemical geomorphological, geophysical and ecosystematic research in the area of the Bulgarian station St. Kliment Ohridski". The project is funded by the Ministry of Environment and Water of the Republic of Bulgaria and it extended from 2005 until 2010 year. 
The Bulgarian Antarctic base "St. Kliment Ohridski" (S62 38'25.7”, W60²1'54.9”, 13 m a.s.l.) is located in the South Bay of Livingston Island, South Shetland archipelago. The coast has length of $1.8 \mathrm{~km}$ and it contains alternate sections with predominate abrasion or accumulation processes. During (Fig. 1-8 see the color paste between pages 88 and 89 ):

Bulgarian beach or so called Big Lagoon, where is situated the Bulgarian base;

- Greenpeace - a rocky section with bench, which jutes out into the sea;

- Stripes beach;

- Fiord 1 - rocky section with a niche, in which the sea deposits material during high tides;

- High beach;

- The Cave - rocky section with a niche;

- Bench 1 - extension of the rocky section, where the abrasion platform is well developed;

- Little cove;

- North lagoon - a new uncovered by the glacier territory, showed on the last few years.

- Reserve harbor - a little beach south from BAB and the gore Punta Hesperides.

The abrasion is in relation with the surf waves, the storm, the petrograhical type of the rocks, the weathering, the sea soup activity, the activity of the glacier tongues and the tides. The mean high tides are 1,50-1,60 $\mathrm{m}$ in height but their width depends from so called straight stream. i.e. the angle by which the surf reaches the coast, from the rock inclinations into the sea and from the elevation of the coast line. In 2008 was defined the width of the tidal zone:

- In the Bulgarian beach - between 18 and $22 \mathrm{~m}$;

- In the North lagoon $-7,5 \mathrm{~m}$,

- In the High beach $-9,2 \mathrm{~m}$.

On the beaches the main accumulative forms are the beach ridges which form 2 marine terraces (low and high) and alternate stripes of fine and coarse pebble on the flat platforms. Often on those platforms in the summer are forming lakes from the little steams, coming from the glacier.

Lopes-Martines et al. (1992) referred both ridges as high marine terrace but the field studies confirmed that the low terrace marks the tidal zone and the highest one is fragmentary developed and covered with debris materials and fluvioglacial deposits.

The high terrace is situated closer to the cliff. It has height 3-5 $\mathrm{m}$ but it is fragmentary developed. There are fragments of it in the Big Lagoon beach, in the Reserve harbor, the Stripes beach, the High beach, the Little Cove and behind the river in the North Lagoon. In the Stripes beach parts of it are frozen. The origin of the material is marine but it was mixed with fluvioglacial. Currently not the abrasion is the main factor which is influencing this form but ablation, fluvial erosion and debris processes.

The structure of the high terrace is shown on Fig. 2 and 3:

In this section the Glacier has bite into the high terrace and parts of the beach. During the summer melting it deposits a mixture of all the materials in its body, which are separating on fine grains, which sink in depth and coarser materials, which remains on the beach. The large, well rounded blocks and pebbles are disks and blades in shape. This is the reason we refer them to the high marine terrace and the smaller ones which are not well rounded we assume as ablation moraine. We recon that the glacier deposits here lie on marine materials.

Deposits are in the gravel fraction, regardless of petrographic types (Table 1). They do not reach $1 \mathrm{~m}$ on axis "a", and their average dimensions (the three axes "a", "b", "c") 60/47, 75/26, 3 $\mathrm{cm} .75 \%$ of the pieces have been transorted by dragging, and the rest - by the saltation. Interestingly, the smaller pieces have been rolled. In the field description of the profile showed mixing of two types of material - a well rounded granulesl and pebbles, and the other - angular and smaller in size. Large fractions lay in fine materials, which also were rounded and angular. It also includes cracked in situ cobbles. 
Table 1. Results from granulometry analysis of deposits of High marine terrace at Stripes beach

\begin{tabular}{|c|c|c|c|c|c|}
\hline $\mathrm{cm}$ & pebbles & granules & sand & silt+clay & Color (acc. Munsell) \\
\hline $0-11$ & 8,5 & 5,81 & 17,4 & 68,3 & 5 Y 5/1 gray. \\
\hline $11-70$ & 38,79 & 8,32 & 26,3 & 26,6 & Gley 110 GY 5/1 greenish gray \\
\hline $70-90$ & 72,94 & 3,51 & 11,8 & 11,8 & Gley 110 Y 6/1 greenish gray. \\
\hline $90-120$ & 0 & 0,83 & 64,5 & 34,7 & 5Y 5/1 gray; 5Y 5/1 gray. \\
\hline
\end{tabular}

In the table it is clear the diversity in the distribution of fractions. The entire depth of granules content is low and decreases uniformly down. We assume that granules from Deception's volcano ash are at the upper part. The amount of sand in depths of $0-11 \mathrm{~cm}$ and $70-90 \mathrm{~cm}$ is relatively small, and from 11 to $70 \mathrm{~cm}$ and 90 to $120 \mathrm{~cm}$ increased significantly. Factions that are smaller than sand (silt and clay) show different values as observed overall reduction in depth. This is probably related to its elution from seeping water from melting snow and ice. This diversity is reflected in the distribution and sorting of the material: in the upper horizon sediments are mixed fractioned and unevenly distributed, in depth $11-70 \mathrm{~cm}$ are double fractioned, moderately to well sorted, between $70-90 \mathrm{~cm}$, they are again with mixed fractioned uneven distribution, and in the bottom horizon double fractioned, moderately to well sorted.

The low terrace marks the surf zone; its height is $1.5-2.1 \mathrm{~m}$ and its width is $7.5-18 \mathrm{~m}$. It is presented at all beaches across the shore. The material is smaller than this in the high terrace and there is broken pebble (from transportation and frost weathering in situ). Pebbles are well rounded.

Sorting of the material was investigated in profile from the hillside areas of the ocean (Fig. 3). Talus material characterized R13. R14 is taken from the shoreline near the BAB and represents uniform sand section, located in coarse materials, and R15 is fine material from the low terrace nearest the ocean, which contains many granules.

It is significant the low silt and clay content in the three samples (between 1 and $3 \%$ ). The slope material (R13) is characterized by high content of coarse fractions (granules). In the other two samples sand plays a major role - over 70\%. Overlay R13 and R15 are moderately to well sorted, it contains two dominant factions, each with more than $10 \%$ and their sum is over $90 \%$ of the sample. In R13 dominates gravel and sand, while R15 is with fine material. All this shows an increase in large peaces to shore and to slope and in the middle of the lagoon the material is smaller.

The comparison of samples from two terraces (Table 2) showed that the size distribution of high marine terrace exceed at least 2 times those of the lower terrace. The petrographic composition in both dominates sandstone, but in the high marine terrace the percentage is relatively small for account of andesite and diorite. The two terraces have in common the roundness (nearly 4) of the pieces and the prevalence of disk and blades shape.

Table 2. Comparison of the High and the Low marine terrace

\begin{tabular}{|l|c|c|}
\hline \multicolumn{1}{|c|}{ Sample No } & High terrace & Low terrace \\
\hline COUNT (number of pebbles) & 29 & 20 \\
\hline MIN $(\mathrm{cm})$ & $\mathrm{a}-53, \mathrm{~b}-45, \mathrm{c}-18$ & $\mathrm{a}-27, \mathrm{~b}-23, \mathrm{c}-4$ \\
\hline MAX $(\mathrm{cm})$ & $\mathrm{a}-264, \mathrm{~b}-223, \mathrm{c}-93$ & $\mathrm{a}-97, \mathrm{~b}-75, \mathrm{c}-41$ \\
\hline AVERAGE $(\mathrm{cm})$ & $\mathrm{a}-134, \mathrm{~b}-103, \mathrm{c}-53$ & $\mathrm{a}-60, \mathrm{~b}-48, \mathrm{c}-26$ \\
\hline STDEV $(\mathrm{cm})$ & $\mathrm{a}-65, \mathrm{~b}-50, \mathrm{c}-17$ & $\mathrm{a}-19, \mathrm{~b}-15, \mathrm{c}-11$ \\
\hline Predominating petrography sort (\%) & sandstone $-38 \%$ & sandstone - 65\% \\
\hline Mean Roundness (after Cepeбpяный, 1971) & 3,9 & 3,95 \\
\hline Brocken pebble (\%) & 0 & 25 \\
\hline transported by saltation \% (spheroids+rods) & 31 & 25 \\
\hline transported by dragging \% (discs+blades) & 69 & 75 \\
\hline
\end{tabular}


The stripes in the platform sections of the beaches (Fig. 4) are made from alternate coarse (with width 2-3.6 m) and fine material (with width 1-16 m) on a flat platforms on the beach. During the snow melting they show up one by one in the front of the melting-line. At the Stripes beach the pebble stripes are 4 (and they remain so every year). The material in them is very well rounded but there are some angular single pieces from debris coming from the cliff. Their mean size is approximately the same $18 / 10 / 8 \mathrm{~cm}$, only those on the shore line have average size $25 / 20 / 15 \mathrm{~cm}$.

There is an interesting sorting of the material on the beaches from the Ocean to the cliff. It was best observed in the platform in front of the wave-cut notch, called The Cave (Fig. 5). The results from the grain-size analysis of pebbles there is shown on Table 2 . In tectonic crack into the rock descends an ice tongue which has talus cone. With the rapid melting of snow (ice) in a small crack is running a stream which waters sink in the foot. Cove is surrounded by bedrock. The whole territory to the ocean is made up of various sizes and roundness pieces. There was no visible fine material in the surface.

Due to the height of the coast, the zone which is under the influence of tides has a width 4-5 $\mathrm{m}$. For its closure and the absence of other processes it was chosen for comprehensive macroscopic analysis of the stripes that build the territory from the foothills to the ocean. Places in which we analyzed the pieces are set - 1, 2, 3 and 4. № 4 is closest to shore.

Data for the size and roundness (Table 3 ) give us reason to think that the pieces that are closest to the slope are with the smallest size, more angular and with most diverse petrographic composition. In the middle part (places 2 and 3 ) increase the size and roundness. In the closest to the ocean place the pieces reach their maximum in size and roundness. This confirms the slope origin of the pieces in place 1, while others are transported from abrasion. The greatest roundness have those which are closest to the water. They have the largest sizes. We assume that the sand and granules are beneath the coarse pebble and cobble. For debris materials is typical disk shape (although they are angular), and medium and small are more diverse, which suggests a different transport agent. The type of the transportation of the pieces depends on their size: the larger are dragged, but the smaller are rolling. Roundness increases sharply in place 2 . This shows the line of abrasion influence, where also the broken pebble shows up. In the middle the cylindrical and spheroids pieces are more. Immediately to the ocean the size of the pieces and their roundness are highest.

Table 3. Distribution of the material in the niche

\begin{tabular}{|c|c|c|c|c|}
\hline Sample No & 1 & 2 & 3 & 4 \\
\hline $\begin{array}{l}\text { COUNT (number of } \\
\text { pebbles) }\end{array}$ & 19 & 29 & 27 & 15 \\
\hline MIN (cm) & $a-5, b-3, c-2$ & $a-6, b-4, c-2$ & $a-8, b-6, c-4$ & $\begin{array}{c}a-40, b-40, c- \\
20\end{array}$ \\
\hline $\operatorname{MAX}(\mathrm{cm})$ & $\begin{array}{c}a-55, b-48, c- \\
23\end{array}$ & $\begin{array}{c}a-42, b-30, c- \\
30\end{array}$ & $\begin{array}{c}a-50, b-46, c- \\
29\end{array}$ & $\begin{array}{c}a-70, b-50, c- \\
60\end{array}$ \\
\hline AVERAGE $(\mathrm{cm})$ & $a-21, b-15, c-8$ & $\begin{array}{c}a-25, b-18, c- \\
13\end{array}$ & $\begin{array}{c}a-28, b-22, c- \\
16\end{array}$ & $\begin{array}{c}a-53, b-45, c- \\
34\end{array}$ \\
\hline STDEV $(\mathrm{cm})$ & $a-16, b-12, c-5$ & $a-12, b-8, c-8$ & $a-13, b-11, c-7$ & $\mathrm{a}-13, \mathrm{~b}-6, \mathrm{c}-14$ \\
\hline $\begin{array}{l}\text { Predominating } \\
\text { petrography sort }(\%)\end{array}$ & $\begin{array}{l}\text { andesite- } 42, \\
\text { sandstone- } 42\end{array}$ & sandstone- 62 & sandstone - 52 & sandstone -47 \\
\hline $\begin{array}{l}\text { Mean Roundness (after } \\
\text { Серебряный, 1971) }\end{array}$ & 2,9 & 3,9 & 3,6 & 4 \\
\hline Brocken pebble (\%) & 0 & 14 & 0 & 7 \\
\hline Sample No & 32 & 55 & 74 & 80 \\
\hline $\begin{array}{l}\text { COUNT (number of } \\
\text { pebbles) }\end{array}$ & 68 & 45 & 26 & 20 \\
\hline
\end{tabular}


Therefore, in this small bay (from the rock to the ocean) there is a clear sorting of the material from the ocean to the cliff, manifested in changes in their size and roundness.

Regarding the fine grained material, which is present across the study area geochemical survey was done (Fig. 6). It is in glacial tongues, and after the melting it remains in situ or is involved in movement of debris and fluvioglacial processes. Samples were taken (sand fraction and smaller) from different parts of the region, which were compared with similar ones from the neighboring Deception Island. AES ICP analyses showed that the material is very similar in petrographic and chemical composition (Table 4). This means that the fine fractions are the result not so much from the weathering of surface rocks but the transport of volcanic ash from Deception of his previous eruptions.

Regarding the fine grained material, which is present across the study area geochemical survey was done (Fig. 6). It is in glacial tongues, and after the melting it remains in situ or is involved in movement of debris and fluvioglacial processes. Samples were taken (sand fraction and smaller) from different parts of the region, which were compared with similar ones from the neighboring Deception Island. AES ICP analyses showed that the material is very similar in petrographic and chemical composition (Table 4). This means that the fine fractions are the result not so much from the weathering of surface rocks but the transport of volcanic ash from Deception of his previous eruptions.

Table 4. Results from AES ICP analyses of the fine grained materials are made in the "Geochemical laboratory", University of Mining and Geology "St. Ivan Rilski", Sofia

\begin{tabular}{|l|c|c|c|c|c|c|c|c|c|c|c|c|c|}
\hline \multirow{2}{*}{ Samples } & \multicolumn{10}{|c|}{$\%$ \% } \\
\cline { 2 - 12 } & $\mathrm{Al}_{2} \mathrm{O}_{3}$ & $\mathrm{CaO}$ & $\mathrm{Fe}_{2} \mathrm{O}_{3}$ & $\mathrm{~K}_{2} \mathrm{O}$ & $\mathrm{MgO}$ & $\mathrm{MnO}$ & $\mathrm{Na}_{2} \mathrm{O}$ & $\mathrm{P}_{2} \mathrm{O}_{5}$ & $\mathrm{FeO}$ & $\mathrm{SiO}_{2}$ & $\mathrm{TiO}_{2}$ & $3 \mathrm{H}$ & Moisture \\
\hline $\begin{array}{l}\mathrm{R}-20- \\
\text { North } \\
\text { Glacier }\end{array}$ & 15.92 & 7.48 & 9.78 & 0.73 & 4.19 & 0.16 & 3.86 & 0.23 & 3.11 & 55.53 & 1.70 & 0.08 & 0.36 \\
\hline Deception & 16.25 & 8.46 & 9.64 & 0.48 & 4.76 & 0.15 & 3.98 & 0.23 & 4.33 & 53.96 & 1.66 & 0.07 & 0.56 \\
\hline $\begin{array}{l}\text { R-28 } \\
\text { North } \\
\text { Lagoon }\end{array}$ & 16.22 & 7.00 & 10.09 & 0.66 & 3.95 & 0.15 & 3.92 & 0.27 & 2.89 & 54.74 & 1.79 & 0.71 & 0.81 \\
\hline
\end{tabular}

The abrasion forms are the wave-cut platform, part of which are the sea stacks in the foreshore, the wave-cut cliff with notches and potholes, in which are holding "nests" of marine pebble. Part of the abrasion forms are also the remaining rocks on the beaches. The abrasion forms are developed in connection with lithology, where there are outcrops of dykes and hypoabisal reefs of the Hesperides Pluton (Fig. 7). The wave-cut platform has width from 3-4 to 8-10 m at each outcrop.

The Stripes beach and the High beach are separated by a cliff that descends to the ocean and forms outcrop (so called fiord) and bench. Measurements were made in the area (so called) Fiord 1 on three walls with a southern and northern exposure (Fig. 8). We believe that this site characterized the effects of abrasion on the large size material: cobbles and pebble. Perceive depth reduction as a result of accumulation, and increasing as a result of transport and sinking into the depths. Fiord 1 is filled with some of the largest deposits of the beach and therefore we recon changes from 1-2 to $5 \mathrm{~cm}$ as a result of a "center pivot" of gravel along the axes in depth, rather than transport (Table 5).

Depth measurements of the three walls over the period showed the following values:

Based on the results from these measurements we could make the following conclusions:

- For 9A with a southern exposure: during the entire period there is only depth reduction (from 115 to $70 \mathrm{~cm}$ ); 9B with a northern exposure - 2 times increasing and reduction and after all reduction ultimately prevails $(120-71 \mathrm{~cm})$; $9 \mathrm{C}$ (also with southern exposure) also noted a reduction, which is the highest value - from 154 to $76 \mathrm{~cm}$. We accept that in 9A and 9C has an 
accumulation of material, but in 9B has reduction and deposition. Overall, however, dominates accumulation.

Table 5. Depth changes in the deposits

\begin{tabular}{|c|c|c|c|c|}
\hline $\begin{array}{l}\text { On } 10.01 .2006- \\
\text { measured depths of the } \\
\text { three walls in the } \\
\text { beginning of high tide: } \\
\text { 9A South exposure- } \\
115 \mathrm{~cm} \text {; } \\
\text { 9B North exposure - } \\
117 \mathrm{~cm} \text {; } \\
9 \mathrm{C} \mathrm{South} \text { exposure - } \\
154 \mathrm{~cm} \text {; }\end{array}$ & $\begin{array}{l}\text { On } 07.01 \text { and } \\
\text { on } 14.01 .2007 \\
\text { are measured } \\
\text { the same } \\
\text { results. They } \\
\text { were confirmed } \\
\text { in the end of } \\
\text { the season. } \\
\text { - } 9 A-113 \mathrm{~cm} \text {; } \\
\text { - } 9 B-120 \mathrm{~cm} \text {; } 9 C-112 \mathrm{~cm}\end{array}$ & $\begin{array}{l}\text { On } 11.01 .2008 \\
\text { are measured the } \\
\text { following depths } \\
\text { - } 9 A-\text { covered } \\
\text { with snow, no } \\
\text { data; } \\
\text { - } 9 B-94 \mathrm{~cm} \text {; } \\
\text { - } 9 C-66 \mathrm{~cm} \text {; } \\
\text { On } 20.01 \text { melting } \\
\text { begins during } \\
\text { warming and } \\
\text { rain. }\end{array}$ & $\begin{array}{l}\text { On } 23.12 .2008 \\
\text { are measured } \\
\text { the following } \\
\text { depths: } \\
\text { - } 9 A-\mathbf{1 0 0} \mathrm{cm} \text {; } \\
\text { - } 9 B-89 \mathrm{~cm} \text {; } \\
\text { - } 9 C-93 \mathrm{~cm} \text {; } \\
\text { On } 21.01 .2009 \\
\text { are measured } \\
\text { the following } \\
\text { depths: } \\
\text { - } 9 A-98 \mathrm{~cm} \text {; } \\
\text { - } 9 B-83 \mathrm{~cm} ; \\
\text { - } 9 C-93 \mathrm{~cm} ;\end{array}$ & $\begin{array}{l}\text { On 07.01.2010 } \\
\text { are measured } \\
\text { the follow- } \\
\text { ing depths: } \\
\text { - } 9 \text { A-91 cm; } \\
\text { - } 9 B-104 \mathrm{~cm} \text {; } \\
\text { - } 9 \text { - covered } \\
\text { with snow, no } \\
\text { data; } \\
\text { On } 12.01 .2010 \text { : } \\
\text { - } 9 A-70 \mathrm{~cm} \text {; } 9 B-90 \mathrm{~cm} \text {; } \\
\text { - } 9 C-76 \mathrm{~cm} \text {; } \\
\text { On } 22.01 .2010 \text {; } \\
\text { - } 9 A-70 \mathrm{~cm} ; \\
\text { - } 9 B-71 \mathrm{~cm} ; \\
\text { - } 9 C-73 \mathrm{~cm} \text {; }\end{array}$ \\
\hline
\end{tabular}

- For all the walls changes are greatest in the period 2007-2008, and are associated with accumulation. This coincides with the activation of slope processes and weathering. At the same time, there are very little changes in 2006-2007.

- The biggest changes are to the wall with southern exposure.

\section{Conclusion}

Along the coast the main forms that are revealed are: pebble beaches with moraines and terraces, bench, steep cliff, jutting rocks in the ocean, niches. From them the largest area is occupied by pebble beaches and minor - niches.

In the area of the beach can be seen two terraces:

- One of them marks the line reached by the tides. This is the low terrace, which is developed almost everywhere with the exception of places where the bench show. The terrace has an excess of 0,7 to $1,5 \mathrm{~m}$ and in very rare cases (North Lagoon) reaches $2 \mathrm{~m}$. It is composed of well rounded cobbles (and less pebbles) with a disk shape, something that indicates dragging the pieces. In contrast, the smaller pieces are transported by saltation. These two ways of transportation are significant for the material sorting. The dimensions of the pieces that build this terrace were significantly (more than 2 times in places) smaller than the internal high marine terrace. Their roundness is high, but often seen broken pieces as a result of weathering in situ.

- The other terrace is developed on the slope of the cliff. It has a relatively large excess of $\mathrm{BAB}$ in the region over the lagoon rises of 3-5 m, and near the Reserve harbor - of 6-7 m. Width is 3-5 m. It is widely developed and fragments of it are revealed in Big Lagoon, Reserve harbor, 
High beach and Little cove to the North River Glacier. The material from which it was built of is considerably larger in size than that which builds the low terrace. This is the most well rounded material, regardless of their petrographic composition. About $70 \%$ of the pieces were transported by dragging. This and their high degree of roundness, confirms our view, that their origin is marine and fluvioglacial. This terrace in the observed period is developing under the influence of fluvioglacial streams, glacial activity and slope processes. Now it is in places covered by slope material, while the other is eroded by fluvioglacial streams.

Sorting of the material could be seen in 2 directions:

- From the slopes to the coast and

- From the surface in depth.

In the first case at the foot of the slopes has angled material in various fractions (including fine grains), which lies on the marine smooth pebble. In some places they build the high marine terrace. Throughout the beaches everywhere almost lacks silt and clay fractions, and it has volcanic origin. When snow melts, they sink in depth. The largest mixing of the material is at the foot of the cliff towards the shore. There slope material is mixed with fluvioglacial, glacial (before 4500-4900 BP, Martinez-Lopez, P.) and marine. In many places the slopes and foothills are convex (i.e. they have unprocessed profile). In Big Lagoon sorting of the material is associated with a large material to the slope and terrace to the coast, while in the center of the lagoon sediments are volcanic fine ash.

The zone, which is under the influence of tidal waves have different widths at bay. In areas of the beaches are revealed better smooth the coarse boulders, arranged side by side in places and the space between them is filled by pebble and small granules. In the Stripes beach these boulders have the largest sizes (up to $1.6 \mathrm{~m}$ on axis "a"). In the highest part of this area are deposited small and large pieces of ice soup.

Bench (width of 3-4 to 8-10 m) is determined by the location of the dykes, along which are genetically related with the Hesperides pluto and siltstones.

When more spaces are opening from the retreating glaciers we assume that the territory on which the process of abrasion will be leading will increase.

\section{Literature}

Серебряный, Л. 1980. Лабораторный анализ в геоморфологии. Москва.

Kenderova, R., 2007; Geomorphological Research in the Area of the Bulgarian Antarctic Station on Livingston Island, Part Of South Shetlands, Antarctic. Objective, Approach, Methodology, 4- $^{\text {th }}$ International Conferance Global Changes \& Problems Theory \& Practice, Sofia, 13-16.

Lopes-Martines J., J.M. Vilaplana, E. Martines de Pison, J. Calvet, A. Arche. D. Serraty, R. Pallas, 1992, Geomorphology of Selected Areas in Livingston Island, South Shetland Island. in LÓPEZ-MARTÍNEZ, J. (ed.), Geologia de la Antártida Occidental. Simposios T3, III Congresso Latinoamericano de Geología, Salamanca, p. 271-282. 
Rossitza Kenderova, Christo Pimpirev, Ahinora Baltakova, Stefka Pristavova COASTAL FORMS AND DEPOSITS IN BULGARIAN ANTARCTIC BASE AREA, LIVINGSTON ISLAND

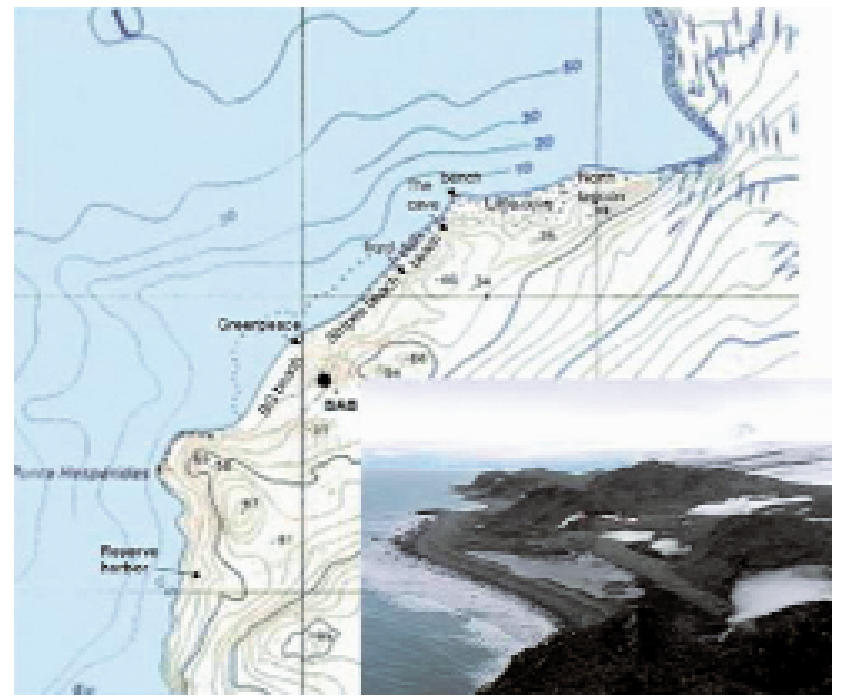

Fig. 1. Sections of the Bulgarian base coast and the Bulgarian beach from bird's eye view.

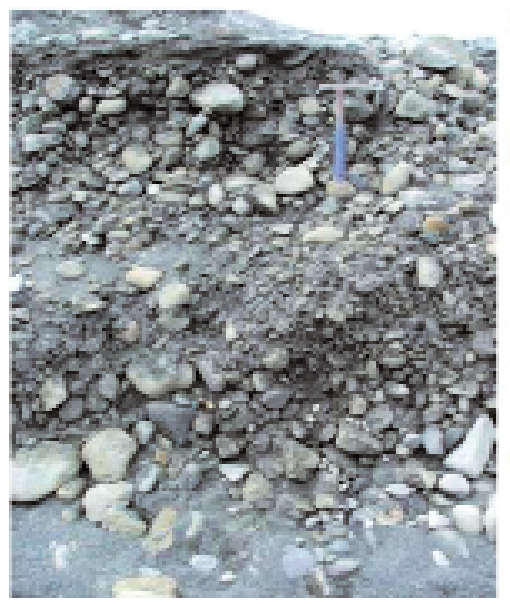

0-11 cm - clay, sand and gravel with single pebble; 5 Y 5/1 gray

$11-70 \mathrm{~cm}$ - sandy or loamy-sand with pebble and gravel, well rounded with max size 20/15/12 cm; Gley 110 GY 5/1 greenish gray;

$70-90 \mathrm{~cm}$ - smaller gravel and increasing of the filling; max size 5/4/3 cm; well rounded; Gley 110 Y 6/1 greenish gray.

90 - $120 \mathrm{~cm}$ - sandy with large and medium pebble; $5 Y$ 5/1 gray

Fig. 2. Outcrop of the High marine terrace at the Stripes beach

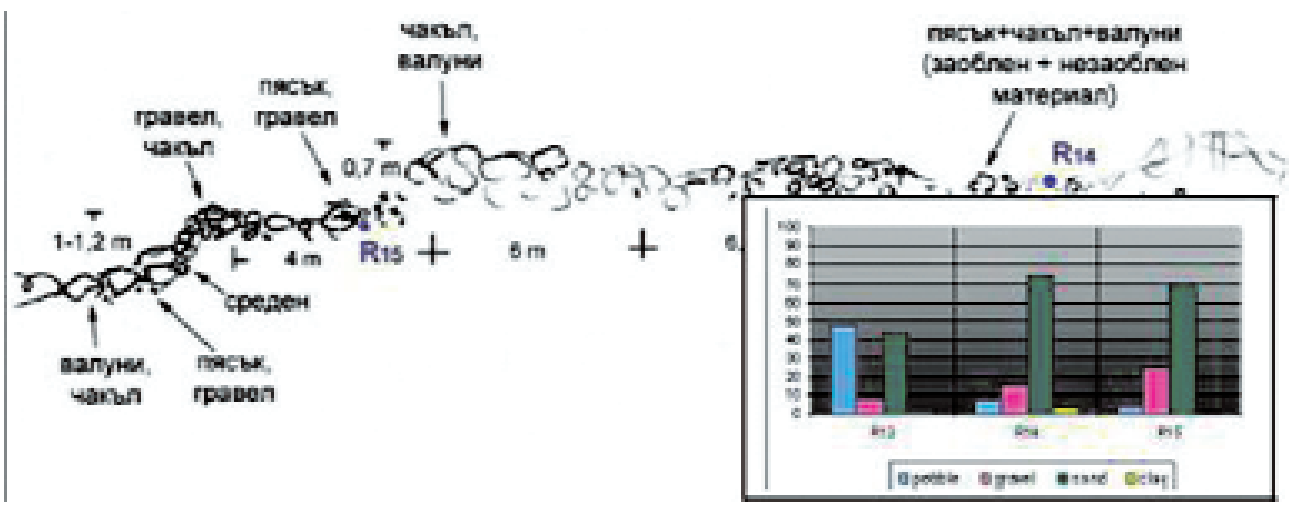

Fig. 3. Cross section of the Bulgarian beach with the Low marine terrace and distribution of the material 


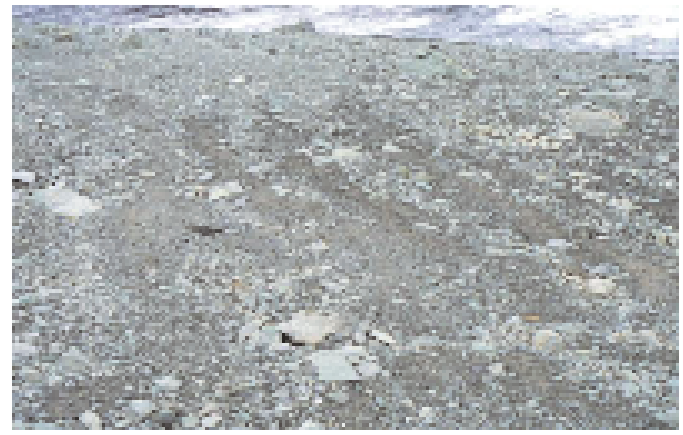

Fig. 4. Alternate stripes of fine and coarse material on a flat platform (Stripes beach)

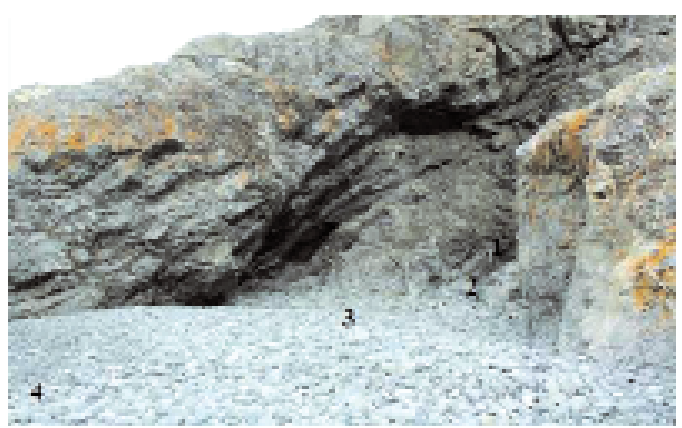

Fig. 5. Deposits sorting at the Cave (wave-cut notch)

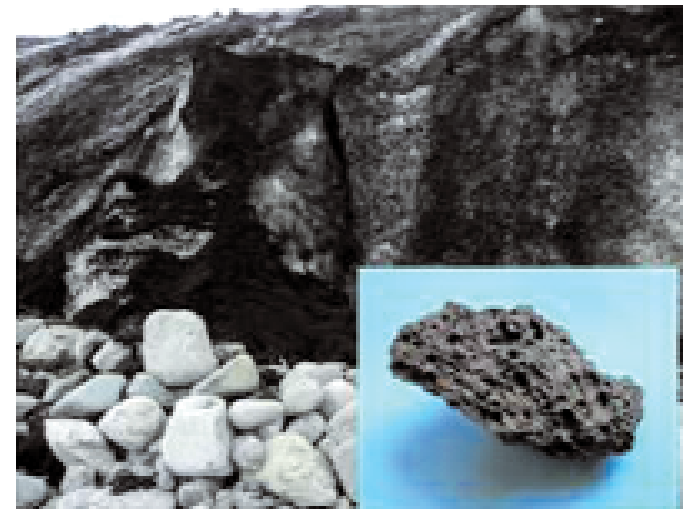

Fig. 6. Volcanic ach from Deception eruptions, which forms the fine grained consistent of all the samples

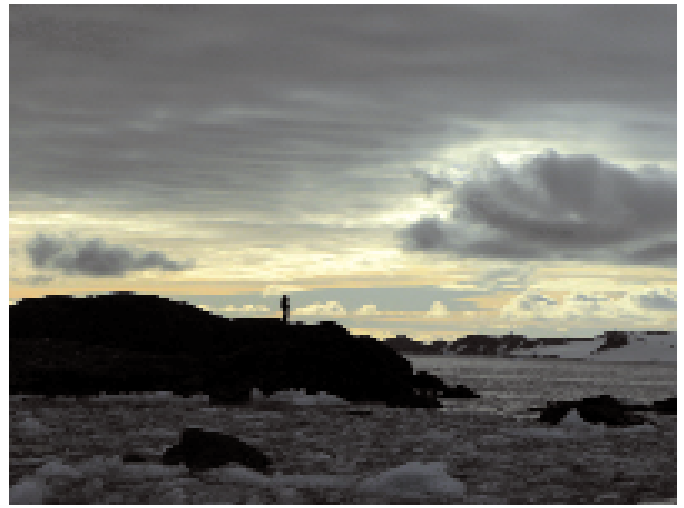

Fig. 7. Wave-cut platform with sea stacks at Greenpeace rock
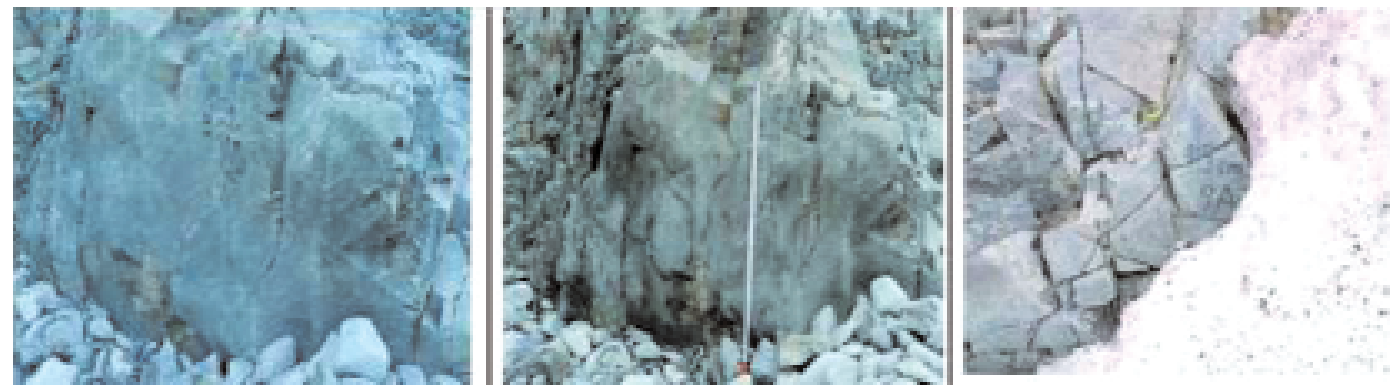

Fig. 8. The three observed walls at Fiord 1 